\title{
Crucial roles of thymidine kinase 1 and deoxyUTPase in incorporating the antineoplastic nucleosides trifluridine and 2'-deoxy-5-fluorouridine into DNA
}

\author{
KAZUKI SAKAMOTO, TATSUSHI YOKOGAWA, HIROYUKI UENO, KEI OGUCHI, \\ HIROMI KAZUNO, KEIJI ISHIDA, NOZOMU TANAKA, AKIKO OSADA, YUKARI YAMADA, \\ HIROYUKI OKABE and KENICHI MATSUO
}

\begin{abstract}
Drug Discovery and Development I, Discovery and Preclinical Research Division, Taiho Pharmaceutical Co., Ltd., Tsukuba, Ibaraki 300-2611, Japan
\end{abstract}

Received March 6, 2015; Accepted April 9, 2015

DOI: $10.3892 /$ ijo.2015.2974

\begin{abstract}
Trifluridine (FTD) and 2'-deoxy-5-fluorouridine (FdUrd), a derivative of 5-fluorouracil (5-FU), are antitumor agents that inhibit thymidylate synthase activity and their nucleotides are incorporated into DNA. However, it is evident that several differences occur in the underlying antitumor mechanisms associated with these nucleoside analogues. Recently, TAS-102 (composed of FTD and tipiracil hydrochloride, TPI) was shown to prolong the survival of patients with colorectal cancer who received a median of 2 prior therapies, including 5-FU. TAS-102 was recently approved for clinical use in Japan. These data suggest that the antitumor activities of TAS-102 and 5-FU proceed via different mechanisms. Thus, we analyzed their properties in terms of thymidine salvage pathway utilization, involving membrane transporters, a nucleoside kinase, a nucleotide-dephosphorylating enzyme, and DNA polymerase $\alpha$. FTD incorporated into DNA with higher efficiency than FdUrd did. Both FTD and FdUrd were
\end{abstract}

Correspondence to: Dr Kazuki Sakamoto, Drug Discovery and Development I, Discovery and Preclinical Research Division, Taiho Pharmaceutical Co., Ltd., 3 Okubo, Tsukuba, Ibaraki 300-2611, Japan

E-mail: ka-sakamoto@taiho.co.jp

Abbreviations: 5-FU, 5-fluorouracil; DPM, dipyridamole; dThd, deoxythymidine; dUrd, deoxyuridine; dUMP, deoxyuridinemonophosphate; dUTP, deoxyuridine-triphosphate; DUT, deoxy UTPase; FTD, trifluridine; $\mathrm{F}_{3} \mathrm{dTMP}$, FTD-monophosphate; $\mathrm{F}_{3} \mathrm{dTTP}$, FTD-triphosphate; FITC, fluorescein isothiocyanate; FdUrd, 2'-deoxy-5-fluorouridine; FdUMP, FdUrd-monophosphate; FdUTP, FdUrd-triphosphate; hENT, human equilibrative nucleoside transporter; HPLC, high performance liquid chromatography; LSC, liquid scintillation counting; NBMPR, 6-[(4-nitrobenzyl) thio]-9-( $\beta$ D-ribofuranosyl) purine; TK, dThd kinase; TS, thymidylate synthase

Key words: TAS-102, trifluridine, tipiracil hydrochloride, 5-fluorouracil transported into cells by ENT1 and ENT2 and were phosphorylated by thymidine kinase 1 , which showed a higher catalytic activity for FTD than for FdUrd. deoxyUTPase (DUT) did not recognize dTTP and FTD-triphosphate $\left(\mathrm{F}_{3} \mathrm{dTTP}\right)$, whereas deoxyuridine-triphosphate (dUTP) and FdUrd-triphosphate (FdUTP) were efficiently degraded by DUT. DNA polymerase $\alpha$ incorporated both $\mathrm{F}_{3} \mathrm{dTTP}$ and FdUTP into DNA at sites aligned with adenine on the opposite strand. FTD-treated cells showed differing nuclear morphologies compared to FdUrd-treated cells. These findings indicate that FTD and FdUrd are incorporated into DNA with different efficiencies due to differences in the substrate specificities of TK1 and DUT, causing abundant FTD incorporation into DNA.

\section{Introduction}

Because DNA replication strongly depends on the pool of available deoxyribonucleoside triphosphates, the intracellular metabolism of tumor cells adapts to facilitate rapid proliferation. Accordingly, nucleic acid metabolism is one of the most upregulated pathways in tumor tissues $(1,2)$. Thus, the pyrimidine synthesis pathway involving deoxythymidine (dThd; Fig. 1) biosynthesis was recognized in early studies as a target for solid tumor chemotherapy with drugs, such as 5-fluorouracil (5-FU) and/or antifolate agents $(3,4)$.

Thymidylate synthase (TS), the target of 5-FU and antifolate drugs, is highly expressed in various tumor tissues and is the sole de novo enzyme of dThd synthesis. TS catalyzes the methylation of deoxyuridine monophosphate (dUMP) to dTMP (5-7). However, the dThd salvage pathway involves multiple factors, such as nucleoside transporters and dThd kinases (TK). TK1 is expressed in the cytoplasm during $\mathrm{S}$ phase (8), while TK2 expression is localized to mitochondria and is cell cycle independent (9). TK1 and TS are highly upregulated in various tumor tissues (7) and may serve as potential targets for cancer therapy. However, antitumor agents targeting the dThd salvage pathway have yet to be developed clinically.

Trifluridine (FTD; Fig. 1) is a thymidine-derived nucleoside first synthesized by Heidelberger et al in 1964 as an antitumor 

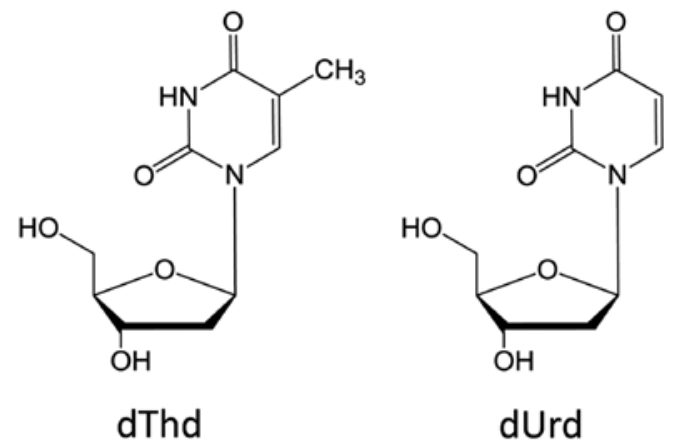

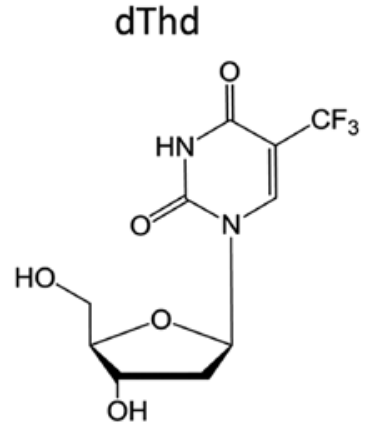

FTD

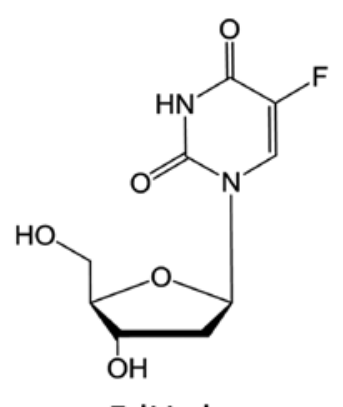

FdUrd
Figure 1. Structures of natural and analog pyrimidine nucleosides.

agent (10), and clinical trials using FTD for monotherapy have been conducted in US (11). However, these trials showed an unexpected toxicity, and FTD was later repurposed as the ocular antiviral drug Viroptic ${ }^{\circledR}(12)$. FTD is well absorbed, but it is easily degraded by the hepatic enzyme thymidine phosphorylase (TP) following oral administration. TAS-102 is an oral combination of FTD and tipiracil hydrochloride (TPI) that prevents FTD degradation by TP (13). Co-administration of TPI and FTD increases the overall FTD concentration in the body, leading to augmented antitumor activity (14).

Recently, TAS-102 treatment showed prolonged survival in patients with metastatic colorectal cancer (mCRC) that were refractory or intolerant to standard chemotherapies including 5-FU, oxaliplatin and CPT-11, in a KRAS mutation-independent manner (15). Based on this phase II result, TAS-102 was launched in Japan in May 2014 as an agent for treating unresectable advanced and recurrent colorectal cancers. The antitumor activity of FTD occurs via two distinct mechanisms, namely, TS inhibition by the mononucleotide form of FTD $\left(\mathrm{F}_{3} \mathrm{dTMP}\right)$ and DNA incorporation itself $(16,17)$. Previous studies have shown that the mechanism of TS inhibition of FTD is different from that of 5-FU $(18,19)$. Moreover, in the phase II study mentioned above, TAS-102, showed efficacy in patients who were progressive after treatment with 5-FU, confirming that FTD and 5-FU have different mechanisms of cytotoxicity.

TS inhibition by the metabolites of FTD or FdUrd (Fig. 1), a clinically active 5-FU analog, has been described by Reyes and Heidelberger (20). Both nucleosides were reported to be metabolized by dThd salvage pathway, involving the nucleoside transporter family members hENT and TK1 (21-23). However, the DNA incorporation profiles regarding substrate specificities in DNA extension reactions by DNA polymerase were not compared. Moreover, in terms of nucleoside triphosphate specificity during DNA synthesis, deoxyUTPase (DUT) plays an important role in DNA replication and 5-FU sensitivity. DUT functions as a gatekeeper protein to prevent the misincorporation of deoxyuridine-triphosphate (dUTP) into DNA by converting dUTP to dUMP. DUT also converts FdUTP (FdUrd-triphosphate) to FdUMP (FdUrd-monophosphate) and prevents FdUTP misincorporation, such that high DUT expression causes 5-FU resistance (24).

These phenomena indicate that the incorporation of 5-FU metabolites and dUTP into DNA are important for 5-FU cytotoxicity, but investigations regarding the DNA incorporation profile of FTD have been limited (25). Therefore, we studied the levels of FTD and FdUrd incorporation into DNA, as well as the substrate specificities of hENT family members (hENT1 and hENT2), TK1, DUT and DNA polymerase $\alpha$.

\section{Materials and methods}

Chemical and reagents. FTD was obtained from Yuki Gosei Kogyo Co., Ltd. (Tokyo, Japan). TPI was synthesized at Junsei Chemical Co., Ltd. (Tokyo, Japan). dThd, FdUrd and dUrd were purchased from Wako Pure Chemical Industries, Ltd. (Osaka, Japan). [5-methyl- $\left.{ }^{3} \mathrm{H}\right]$ dThd $(25.0 \mathrm{Ci} / \mathrm{mmol})$, [6- $\left.{ }^{3} \mathrm{H}\right] \mathrm{dUrd}(19 \mathrm{Ci} / \mathrm{mmol}),\left[6-{ }^{3} \mathrm{H}\right] \mathrm{FdUrd}(13.5 \mathrm{Ci} / \mathrm{mmol})$, and $\left[6-{ }^{3} \mathrm{H}\right]$ FTD $(10.0 \mathrm{Ci} / \mathrm{mmol})$ were purchased from Moravek Biochemicals (Brea, CA, USA). dNTPs were obtained from Takara Bio (Otsu, Japan). F $_{3}$ dTTP was synthesized in house. Single-stranded DNA oligonucleotides were synthesized by Nihon Gene Research Laboratories (Sendai, Japan).

Cell culture. The human HCT116 colorectal cancer cell line derived from an adult male was obtained from the American Type Culture Collection (ATCC; Manassas, VA, USA) and cultured at $37^{\circ} \mathrm{C}$ with $5 \% \mathrm{CO}_{2}$ in McCoy's $5 \mathrm{~A}$ modified medium supplemented with $10 \%$ fetal bovine serum (FBS). Short tandem repeat profiling was performed to confirm the origin and authenticity of the HCT116 cell line.

Measurement of dThd, FTD and FdUrd incorporation into DNA. HCT116 cells $\left(1 \times 10^{7}\right)$ were seeded overnight in $175-\mathrm{cm}^{2}$ culture flasks. Subsequently, cells were incubated with drug mixtures containing tritium-labeled nucleosides at a final concentration of $1 \mu \mathrm{mol} / 1$. The cells were harvested at 1 , 2, 4, 10 and $24 \mathrm{~h}$ after treatment with each drug. DNA was extracted from cell pellets using a DNeasy Blood \& Tissue kit (Qiagen, Hilden, Germany). The resulting DNA solutions were dissolved in $10 \mathrm{ml}$ of Ultima Gold AB liquid scintillation fluid (Perkin-Elmer, Tokyo, Japan). Radioactivity in the samples was measured with a Tri-Carb 2900TR liquid scintillation analyzer (Perkin-Elmer), and the incorporation of tritium-labeled nucleosides into DNA was quantitated. DNA concentrations were determined using the Qubit ${ }^{\circledR}$ dsDNA BR assay kit (Life Technologies, Carlsbad, CA, USA).

Transport experiments. Nucleoside transport was evaluated by the silicone layer method (26). Briefly, cells were harvested the day before experiments began and suspended in transport medium containing $125 \mathrm{mmol} / \mathrm{l} \mathrm{NaCl}, 4.8 \mathrm{mmol} / \mathrm{l}$ $\mathrm{KCl}, 5.6 \mathrm{mmol} / 1 \mathrm{D}$-glucose, $1.2 \mathrm{mmol} / 1 \mathrm{CaCl}_{2}, 1.2 \mathrm{mmol} / \mathrm{l}$ $\mathrm{KH}_{2} \mathrm{PO}_{4}, 12 \mathrm{mmol} / 1 \mathrm{MgSO}_{4}$, and $25 \mathrm{mmol} / 1 \mathrm{HEPES}(\mathrm{pH} 7.4$ ). Cell suspensions were pre-incubated for $20 \mathrm{~min}$ at $37^{\circ} \mathrm{C}$ in 
transport medium, centrifuged, and the resultant cell pellets were resuspended in transport medium ( $\mathrm{pH}$ 7.4) containing a radiolabeled nucleoside or nucleoside analog to initiate uptake. At appropriate times, $160-\mu 1$ aliquots of cell suspension were withdrawn, and cells were separated by centrifugation through a layered mixture of silicone oil (SH550; Dow Corning Toray, Tokyo, Japan) and liquid paraffin (Wako Pure Chemicals Industries) with a density of $1.03 \mathrm{~g} / \mathrm{ml}$. Cell pellets were solubilized in $3 \mathrm{~mol} / \mathrm{l} \mathrm{KOH}$ and then neutralized with $\mathrm{HCl}$. Next, cell-associated radioactivities were measured using a Tri-Carb 2900TR liquid scintillation analyzer. The cellular protein content was determined using the Qubit ${ }^{\circledR}$ Protein assay kit (Life Technologies).

Active recombinant protein expression and purification of TK1 and DUT. The pENTR221/TK1 and pENTR221/DUT constructs were obtained from Life Technologies. A Gateway LR reaction was performed to subclone the fusion partners into the Gateway bacterial expression vector $\mathrm{pEXP1/DEST}$. Transformed BL21 Star ${ }^{\mathrm{TM}}$ (DE3) pLysS cells were grown for $10 \mathrm{~h}$ at $37^{\circ} \mathrm{C}$ in $\mathrm{LB}$ medium containing $100 \mu \mathrm{g} / \mathrm{ml}$ ampicillin. Gene expression was induced by adding isopropyl $\beta$-D-1thiogalactopyranoside $(0.1 \mu \mathrm{mol} / \mathrm{l})$ that was cooled to $10^{\circ} \mathrm{C}$. After $18 \mathrm{~h}$ of induction at $25^{\circ} \mathrm{C}$, bacteria were collected by centrifugation, and pellets were stored at $-135^{\circ} \mathrm{C}$ until purification. Bacterial pellets were resuspended in $10 \mathrm{ml}$ BugBuster $^{\circledR}$ HT Protein Extraction reagent (Merck KGaA, Darmstadt, Germany) and incubated for $30 \mathrm{~min}$ at room temperature. Subsequently, the extract was clarified by centrifugal filtration with a $0.4-\mu \mathrm{m}$ filter and purified with an AKTAprime plus with a HiTrap metal chelate column (GE Healthcare, Buckinghamshire, UK).

Analysis of TK1 substrate specificity for dThd, FTD, dUrd and FdUrd. Ten micromolar tritium-labeled nucleosides and nucleoside analogs were incubated for $5 \mathrm{~min}$ at $37^{\circ} \mathrm{C}$ in $100-\mu 1$ reactions containing $150 \mathrm{mmol} / \mathrm{l}$ Tris- $\mathrm{HCl}$ (pH 7.6), $6 \mathrm{mmol} / \mathrm{l}$ ATP, $15 \mathrm{mmol} / 1 \mathrm{MgCl}_{2}, 1 \%$ bovine serum albumin (BSA) and $20 \mathrm{ng}$ recombinant human TK1. Reactions were stopped by the addition of $200 \mu \mathrm{l}$ of methanol and clarified by ultrafiltration. After clarification, solutions were desiccated by exposure to $\mathrm{N}_{2}$ gas, dissolved in $100 \mu 1 \mathrm{H}_{2} \mathrm{O}$, and analyzed by radio-highperformance liquid chromatography (HPLC). HPLC was performed using a 150TR Flow System analyzer (PerkinElmer) and a Prominence Series HPLC system (Shimadzu Corp., Kyoto, Japan) equipped with an ODS reverse-phase column (TSKgel ODS-100V, $250 \mathrm{~mm}$ x $4.6 \mathrm{~mm}, 3 \mu \mathrm{m}$; Tosoh Corp., Tokyo, Japan), with the eluent $[10 \mathrm{mmol} / 1$ phosphate buffer $(\mathrm{pH} 3.0)$ :Acetonitrile = 9:1] set to a flow rate $1.0 \mathrm{ml} / \mathrm{min}$ for $15 \mathrm{~min}$. This procedure enabled quantitation of residual nucleosides and the production of nucleoside monophosphates formed in the reactions just described.

Analysis of DUT substrate specificity for dThd, FTD, dUrd and FdUrd-triphosphate. dUTPase assays were performed as previously described (27). Deoxynucleoside triphosphates (dUTP, dTTP, $\mathrm{F}_{3} \mathrm{dTTP}$ and FdUTP; $30 \mathrm{mmol} / \mathrm{l}$ ) were incubated for $30 \mathrm{~min}$ at $37^{\circ} \mathrm{C}$ in $100-\mu 1$ reactions composed of $50 \mathrm{mmol} / 1$ Tris- $\mathrm{HCl}$ ( $\mathrm{pH} 7.4$ ), $4 \mathrm{mmol} / 1 \mathrm{MgCl}_{2}, 2 \mathrm{mmol} / 1$ 2-mercaptoethanol, $0.1 \% \mathrm{BSA}$ and $100 \mathrm{ng}$ human recombinant
DUT. Reactions were stopped by the addition of $11 \mu \mathrm{l} 4.2 \mathrm{~mol} / \mathrm{l}$ perchloric acid per reaction. Samples were clarified by centrifugation for $10 \mathrm{~min}$ at 13,000 rpm. Supernatants $(70 \mu \mathrm{l})$ were neutralized with $32 \mu \mathrm{l}$ of $1 \mathrm{~mol} / 1 \mathrm{~K}_{2} \mathrm{HPO}_{4}$, followed by a 10 -min centrifugation at $13,000 \mathrm{rpm}$. Supernatants $(10 \mu \mathrm{l})$ were resolved by HPLC as described above to quantify residual dUTP and newly formed dUMP.

Substrate specificity of dThd, FTD, dUrd and FdUrdtriphosphate for DNA polymerase $\alpha$. Recombinant DNA polymerase $\alpha$ (CHIMERx, WI) activity was assayed according to the manufacturer's recommended protocol. The substrates (dNTPs) were incubated for $30 \mathrm{~min}$ at $37^{\circ} \mathrm{C}$ with $60 \mathrm{mmol} / 1$ Tris- $\mathrm{HCl}$ ( $\mathrm{pH} 7.0$ ), $5 \mathrm{mmol} / 1 \mathrm{MgCl}_{2}, 0.3 \mathrm{mg} / \mathrm{ml}$ BSA, $1 \mathrm{mmol} / 1 \mathrm{DTT}, 0.1 \mu \mathrm{mol} / 1,0.5 \mathrm{U}$ DNA polymerase $\alpha$, fluorescein isothiocyanate (FITC)-labeled primer (5'-FITCGTAAAACGACGGCCAGT-3'), and $0.1 \mu \mathrm{mol} / 1$ synthetic DNA template (5'-TCG $\underline{G A C T G G C C G T C G T T T T A C-3 ', ~}$ 5'-TCGㅡACTGGCCGTCGTTTTAC-3', 5'-TCGㅅACTGGC CGTCGTTTTAC-3', or 5'-TCGTACTGGCCGTCGTTTT $\left.\mathrm{AC}-3^{\prime}\right)$. The underlined sequences represent nucleotides that were modified partially to confirm the sites where $\mathrm{F}_{3} \mathrm{dTTP}$ and FdUTP were inserted.

After the enzyme reactions were complete, samples were resolved by electrophoresis on an ERICA-S system (DRC, Tokyo, Japan) at $300 \mathrm{~V}$ for $3.5 \mathrm{~h}$, and FITC-fluorescence was detected using an ImageQuant LAS 4010 imager (GE Healthcare).

Morphological analysis of HCT116 cell nuclei treated with FTD and FdUrd. For electron microscopy studies, samples were fixed with $2 \%$ paraformaldehyde and $2 \%$ glutaraldehyde, after which they were exposed to $2 \%$ osmium tetroxide. Following dehydration with a graded ethanol series, samples were transferred to resin quetol 812 (Nisshin EM, Tokyo, Japan) and polymerized at $60^{\circ} \mathrm{C}$ for $48 \mathrm{~h}$. The blocks were sectioned at $70 \mathrm{~nm}$ with an Ultracut UCT ultramicrotome (Leica Microsystems, Wetzlar, Germany), and sections were placed on copper grids and stained with $2 \%$ uranyl acetate and lead stain solution (Sigma-Aldrich, Carlsbad, CA, USA). The grids were evaluated using a JEM-1200EX transmission electron microscope (JEOL, Tokyo, Japan).

\section{Results}

Incorporation and elimination of dThd, FTD and FdUrd from DNA in HCT116 cells. Initially, we compared the rates of FTD and FdUrd accumulation into DNA in HCT116 cells with that of the native substrate dThd, using final nucleoside concentrations of $1 \mu \mathrm{mol} / \mathrm{l}$. Fig. 2A shows the time course for nucleoside accumulation at 1, 2, 4, 10 and $24 \mathrm{~h}$ post-exposure. Tritium-labeled nucleosides were used as substrates and were quantified by liquid scintillation counting (LSC). dThd and FTD were incorporated into DNA at comparable levels at the 1- and 2-h time-points. dThd incorporation increased linearly until $10 \mathrm{~h}$, while saturation of FTD incorporation occurred by $4 \mathrm{~h}$, reaching approximately half that observed with dThd (dThd, $41.5 \mathrm{pmol} / \mu \mathrm{g}$ DNA; FTD, $17.6 \mathrm{pmol} / \mu \mathrm{g}$ DNA). However, the level of FdUrd incorporation into DNA was relatively low. For example, after a 24-h incubation, FdUrd incorporation was 

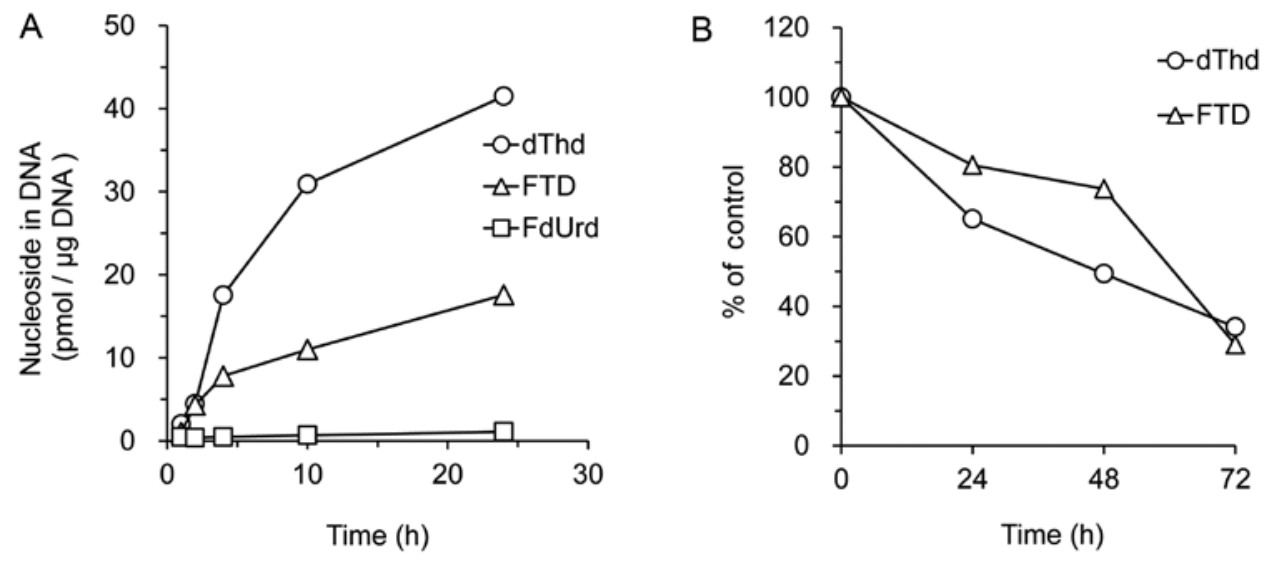

Figure 2. Comparison of dThd, FTD and FdUrd incorporation (A) into DNA and elimination of dThd and FTD (B) from DNA after a washout step. (A) HCT116 cells were treated for $1,2,4,10$ or $24 \mathrm{~h}$ with each compound at $1 \mu \mathrm{mol} / 1$, and DNA incorporation was measured by LSC. (B) Following 24-h treatment with dThd or FTD, these compounds were washed out. At 24, 48 and $72 \mathrm{~h}$ following the washout step, the amount of dThd or FTD remaining incorporated into DNA was measured by liquid scintillation counting. Open circles, triangles and squares represent the incorporation of dThd, FTD and FdUrd, respectively.
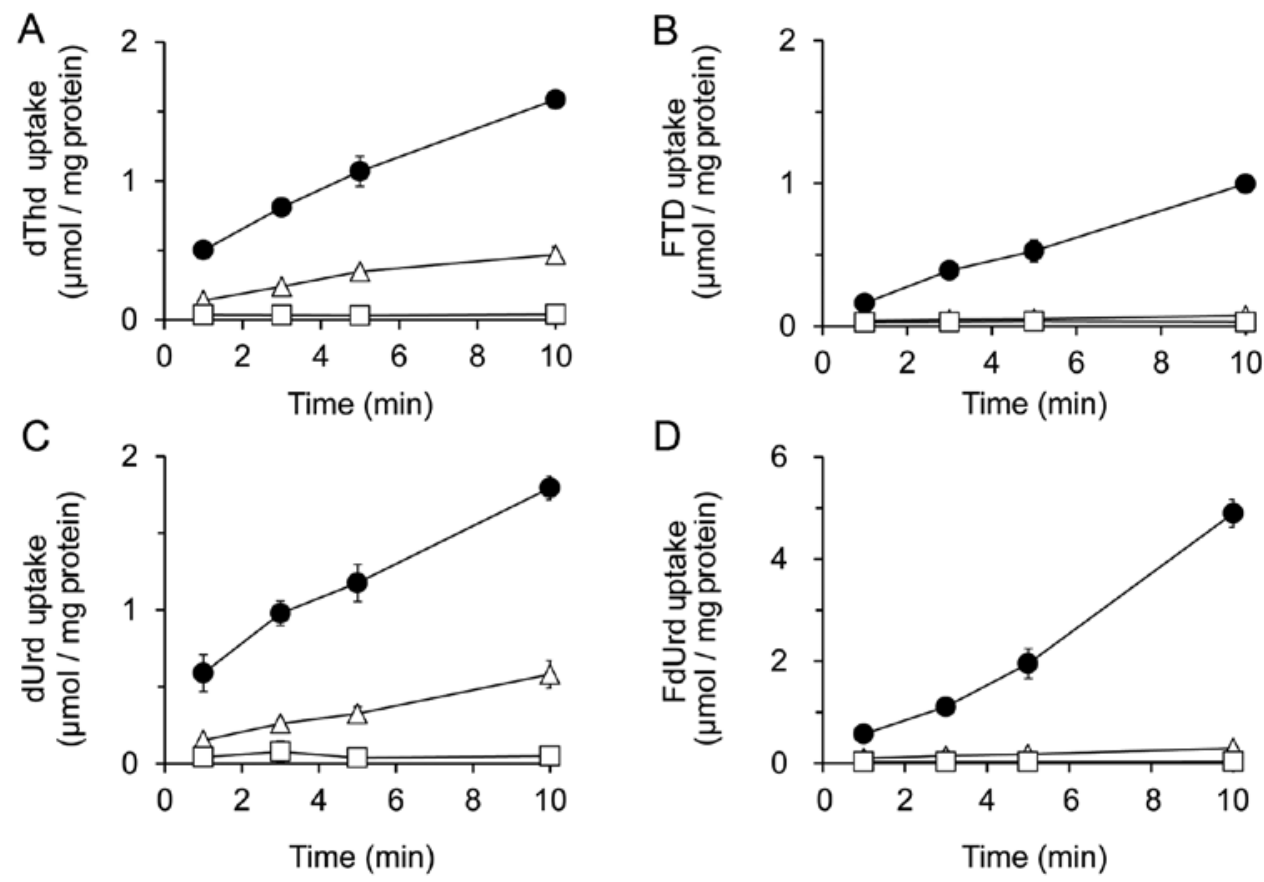

Figure 3. Comparison of uptake levels of $\left.\left.\left[{ }_{3} \mathrm{H}\right] \mathrm{dThd}(\mathrm{A}),{ }_{3} \mathrm{H}\right] \mathrm{FTD}(\mathrm{B}),{ }_{3} \mathrm{H}\right] \mathrm{dUrd}(\mathrm{C})$ and $\left.{ }_{3} \mathrm{H}\right] \mathrm{FdUrd}(\mathrm{D})$ and the effects of nucleoside transporter inhibitors. The uptake of $1 \mu \mathrm{mol} / 1(1 \mu \mathrm{Ci} / \mathrm{ml}) \mathrm{dThd}, \mathrm{FTD}$, dUrd and FdUrd was measured for 1,3,5 and $10 \mathrm{~min}$ by LSC. HCT116 cells were pre-incubated for 10 min at $37^{\circ} \mathrm{C}$ in transport buffer ( $\mathrm{pH} 7.4$ ) before initiating the uptake assay. Closed circles, open triangles and squares represent cellular uptake with a control, $1 \mu \mathrm{mol} / 1$ NBMPR and $10 \mu \mathrm{mol} / 1 \mathrm{DPM}$, respectively. Each result represents the mean $\pm \mathrm{SD}(\mathrm{n}=3)$.

one sixteenth of that observed with FTD (FdUrd, $1.1 \mathrm{pmol} / \mu \mathrm{g}$ DNA), which is close to the limit of detection.

Next, we compared the susceptibility of FTD to elimination from DNA with that of dThd. In this assay, cells were treated with $1 \mu \mathrm{mol} / 1$ dThd and FTD for $24 \mathrm{~h}$, after which drug-free medium was added and the cells were incubated for an additional 24,48 or $72 \mathrm{~h}$. Fig. 2B shows the residual ratios of dThd to FTD at 24, 48 and $72 \mathrm{~h}$ after the washout steps. Both dThd and FTD incorporation into DNA decreased gradually after the washout step, and only minor differences were observed between dThd and FTD (dThd 34.1\%, FTD: $29.0 \%$ ). We also attempted to assess FdUrd elimination from DNA after the washout step; however, it was nearly undetectable in this assay and could not be evaluated.

Intracellular uptake of dThd, FTD, dUrd and FdUrd in HCT116 cells. To monitor the transport of FTD and FdUrd into the cytoplasm and their intracellular uptake, the inhibitory effects of the nucleoside transporter inhibitors 6-[(4-nitrobenzyl)thio]-9-( $\beta$-D-ribofuranosyl) purine (NBMPR) and dipyridamole (DPM) were analyzed and compared to the native substrates dThd and dUrd, respectively (Fig. 3). The concentration of inhibitors used was based on the concentration of NBMPR required to inhibit ENT1, or that required for DPM inhibition of both ENT1 and ENT2 (28). 
Table I. The affinity of TK1 for dThd, FTD, dUrd and FdUrd.

\begin{tabular}{lcccc}
\hline Substrate & $\begin{array}{c}\mathrm{K}_{\mathrm{m}} \\
(\mu \mathrm{mol} / \mathrm{l})\end{array}$ & $\begin{array}{c}\mathrm{V}_{\max } \\
(\mathrm{pmol} / \mathrm{min} / \mathrm{ng} \text { protein })\end{array}$ & $\begin{array}{c}\mathrm{k}_{\mathrm{cat}} \\
(\mathrm{min})\end{array}$ & $\begin{array}{c}\mathrm{k}_{\mathrm{cat}} / \mathrm{K}_{\mathrm{m}} \\
\left(\mathrm{x} 10^{6} / \mathrm{min} \cdot \mathrm{mol}\right)\end{array}$ \\
\hline dThd & 1.16 & 0.70 & 17.78 & 15.28 \\
FTD & 2.34 & 0.93 & 10.26 & 19.26 \\
dUrd & 4.23 & 0.30 & 7.65 & 1.81 \\
FdUrd & 3.33 & 0.51 & 12.97 & 3.86 \\
\hline
\end{tabular}

Tritium-labeled nucleosides were incubated for $5 \mathrm{~min}$ at $37^{\circ} \mathrm{C}$ in a $100-\mu 1$ reaction buffer containing human TK1. Input substrate nucleosides and nucleotides produced by TK1 were analyzed by HPLC.

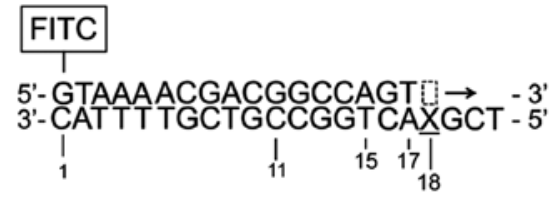

A

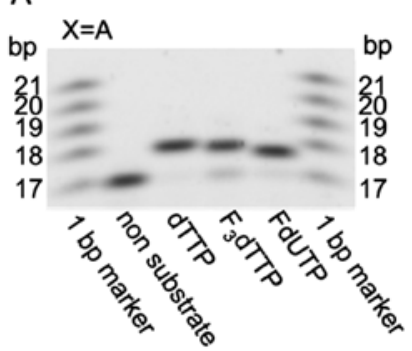

B
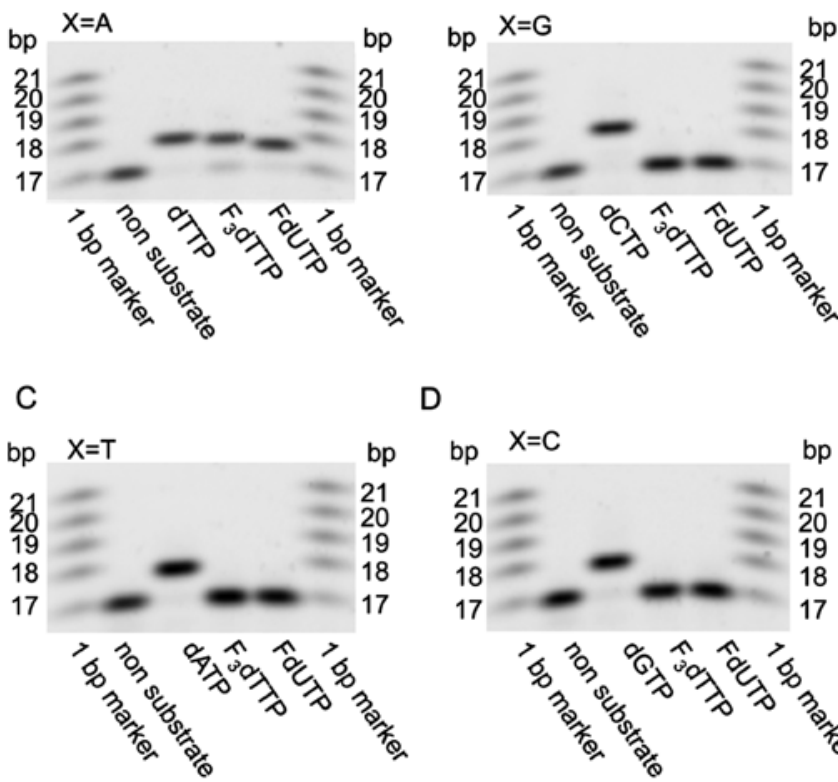

D

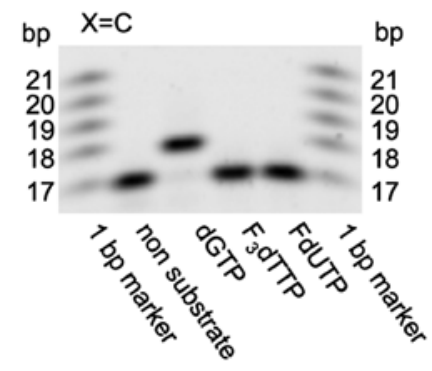

Figure 4. Substrate specificity of DNA polymerase $\alpha$ for incorporating the triphosphate forms of FTD, dUrd and FdUrd into the complement DNA strand at sites matching adenine (A), guanine (B), thymine (C), or cytosine (D). Substrates were incubated for $30 \mathrm{~min}$ at $37^{\circ} \mathrm{C}$ in reaction buffer containing a single-stranded DNA oligonucleotide hybridized to an FITC-labeled primer $(0.1 \mu \mathrm{mol} / 1)$ and DNA polymerase $\alpha$. After reactions were completed, the samples were denatured and electrophoresed on a denaturing acrylamide ge at $300 \mathrm{~V}$ for $3.5 \mathrm{~h}$.

After incubating HCT116 cells with dThd or FTD for $10 \mathrm{~min}$, we found that the inhibitory effect of $1 \mu \mathrm{mol} / 1 \mathrm{NBMPR}$ was less than that of $10 \mu \mathrm{mol} / 1 \mathrm{DPM}$. For instance, the levels of cellular dThd uptake at 10-min post-treatment with a vehicle control, $1 \mu \mathrm{mol} / 1 \mathrm{NBMPR}$, or $10 \mu \mathrm{mol} / 1 \mathrm{DPM}$ were $1.59 \pm 0.06$, $0.47 \pm 0.06$ or $0.04 \pm 0.01 \mathrm{nmol} / \mathrm{mg}$ protein, respectively, while those for FTD uptake were $1.00 \pm 0.04,0.07 \pm 0.01$ and $0.03 \pm 0.02 \mathrm{nmol} / \mathrm{mg}$ protein, respectively (Fig. $3 \mathrm{~A}$ and $\mathrm{B}$ ).

HCT116 cells were also incubated with dUrd and FdUrd for $10 \mathrm{~min}$, and inhibition by $1 \mu \mathrm{mol} / 1 \mathrm{NBMPR}$ was again lower than that by $10 \mu \mathrm{mol} / 1 \mathrm{DPM}$. The levels of dUrd uptake at 10 -min post-incubation with a vehicle control, $1 \mu \mathrm{mol} / 1$ NBMPR, or $10 \mu \mathrm{mol} / 1 \mathrm{DPM}$ were $1.80 \pm 0.08,0.58 \pm 0.09$ and $0.05 \pm 0.01 \mathrm{nmol} / \mathrm{mg}$ protein, respectively, and those of FdUrd were $4.90 \pm 0.27,0.29 \pm 0.07$ and $0.03 \pm 0.00 \mathrm{nmol} / \mathrm{mg}$ protein, respectively (Fig. 3C and D). These results indicate that all nucleosides tested in these experiments could be recognized and transported into cells by both ENT1 and ENT2.

Analysis of TK1 affinities for dThd, FTD dUrd and FdUrd. To evaluate the substrate specificity of FTD, dUrd and FdUrd for TK1, recombinant human TK1 was incubated with tritiumlabeled substrates. The $\mathrm{K}_{\mathrm{m}}$ values determined for each tested nucleoside revealed that dThd analogs had a higher affinity for TK1 than for dUrd analogs (Table I). The $\mathrm{V}_{\max }$ values of dThd-based compounds exceeded those of the dUrdbased compounds. FTD and FdUrd showed higher affinities compared to the native form of these nucleosides, namely, dThd and dUrd.

To evaluate the catalytic efficiency of TK1 in phosphorylating dThd, FTD, dUrd and FdUrd, $\mathrm{k}_{\mathrm{cat}} / \mathrm{K}_{\mathrm{m}}$ ratios were calculated. The $\mathrm{k}_{\mathrm{cat}} / \mathrm{K}_{\mathrm{m}}$ values of $\mathrm{dThd}$ and its analog FTDs tended to be higher than those of dUrd and its analog FdUrd (Table I). TK1 showed higher catalytic efficiency in phosphorylating FTD than it did with dThd, and the catalytic efficiency of FTD phosphorylation by TK1 was $\sim 4$-fold higher than that of FdUrd.

Substrate specificity of DUT for the triphosphate forms of $d T h d, F T D, d U r d$ and FdUrd. Pyrimidine triphosphate incorporation into DNA is strictly regulated by DUT $(29,30)$ and high DUT expression is reported in various types of cancer, suggesting that DUT may confer resistance to 5-fluoropyrimidines $(24,30)$. To determine whether FTD is substrate of DUT, we performed enzymatic assays with recombinant human DUT and either FdUTP or $\mathrm{F}_{3} \mathrm{dTTP}$ (Table II). Although DUT efficiently converted dUTP and FdUTP to their monophosphate forms (dUMP and FdUMP, respectively), dTTP and $\mathrm{F}_{3} \mathrm{dTTP}$ were not found to be substrates for DUT.

Substrate specificity of DNA polymerase a for dThd, FTD, $d U r d$ and FdUrd-triphosphate. Next, we investigated whether $\mathrm{F}_{3} \mathrm{dTTP}$ and FdUTP serve as substrates for DNA polymerase $\alpha$, the responsible enzyme for catalyzing DNA replication. We analyzed extension reactions by DNA polymerase $\alpha$ using 

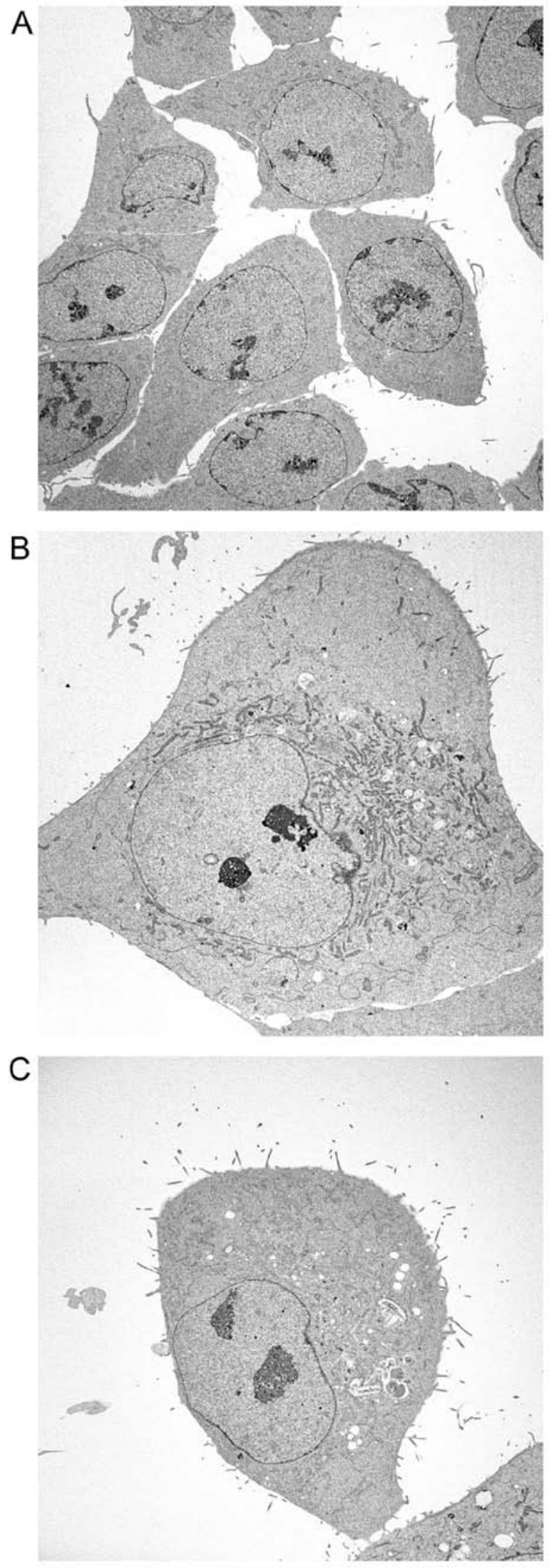

Figure 5. Electron microscopy analysis of untreated HCT116 cells (A), or HCT116 cells treated with FTD (B) or FdUrd (C). Cells were treated in 60 -mm culture dishes with $6 \mu \mathrm{mol} / 1 \mathrm{FTD}$ or $3 \mu \mathrm{mol} / 1$ FdUrd for $72 \mathrm{~h}$, using a concentration found capable of 50\% growth inhibition (data not shown) and subsequently fixed. After dehydration by ethanol treatment, samples were transferred to resin and polymerized. The acceleration voltage of an electron microscope was set at $80 \mathrm{kV}$, and observations were performed under $\mathrm{x} 714$ magnification.
Table II. Substrate specificities of triphosphate form of dThd, FTD, dUrd and FdUrd for DUT.

Production of 5'-monophosphate

Substrate ( $\mathrm{pmol} / \mathrm{min} / 100 \mathrm{ng}$ protein)

$\begin{array}{ll}\text { dTTP } & \text { N.D. } \\ \text { F }_{3} \text { dTTP } & \text { N.D. } \\ \text { dUTP } & 41.4 \\ \text { FdUTP } & 34.8\end{array}$

Thirty micromolar triphosphates were incubated for $30 \mathrm{~min}$ at $37^{\circ} \mathrm{C}$ in buffer containing $100 \mathrm{ng}$ recombinant dUTPase. Samples were analyzed by HPLC to quantify triphosphate and monophosphate formation. N.D., not detectable.

dNTPs (as control substrates) and the triphosphate forms of dUrd, FTD and FdUrd, and a synthetic single-stranded DNA template (Fig. 4). F 3 dTTP and FdUTP, dThd and dUrd were incorporated into the nascent strand at sites matching adenine on the template strand, but not at guanine, cytosine or thymine sites.

Morphological analyses of HCT116 cells treated with FTD and FdUrd. Finally, to compare DNA incorporation data with observable phenotypes, we performed morphological analyses of HCT116 cells treated with FTD and FdUrd by electron microscopy (Fig. 5). Swollen nuclei and structural abnormalities of nucleoli were observed in both FTD- and FdUrd-treated cells (relative to untreated control cells), with the degree of alteration caused by FTD exposure much stronger than that caused by FdUrd. Furthermore, the perinuclear heterochromatin content was decreased by both FTD and FdUrd treatment.

\section{Discussion}

In the present study, we demonstrated that FTD is incorporated into DNA with greater efficacy than is FdUrd (Fig. 6), which resulted from differences in the affinity of TK1 and DUT for these nucleosides. These differences may overcome resistance to FdUrd. The catalytic efficiency of FTD phosphorylation by TK1 is 4-fold higher than that of FdUrd and dUrd. These results imply that TK1 may recognize FTD as dThd, while FdUrd may mimic dUrd. A similar phenomenon was observed for the substrate specificity of DUT. The triphosphate forms of both dUrd and FdUrd were degraded to their monophosphate forms by DUT, while the triphosphate forms of dThd and FTD did not serve as DUT substrates. As a result, FTD-triphosphate was not only produced at a high level, but was also retained for a relatively long duration in DNA (16), compared with FdUrd. In contrast, the monophosphate form of FdUrd may accumulate at a high level, and TS inhibition may be potentiated by DUT.

Regarding the relationship between DNA incorporation and cytotoxicity, we previously reported that one factor promoting higher FTD incorporation than FdUrd incorporation is TS inhibition (17). Indeed, FdUMP derived from FdUrd 


\section{FTD (TAS-102)}
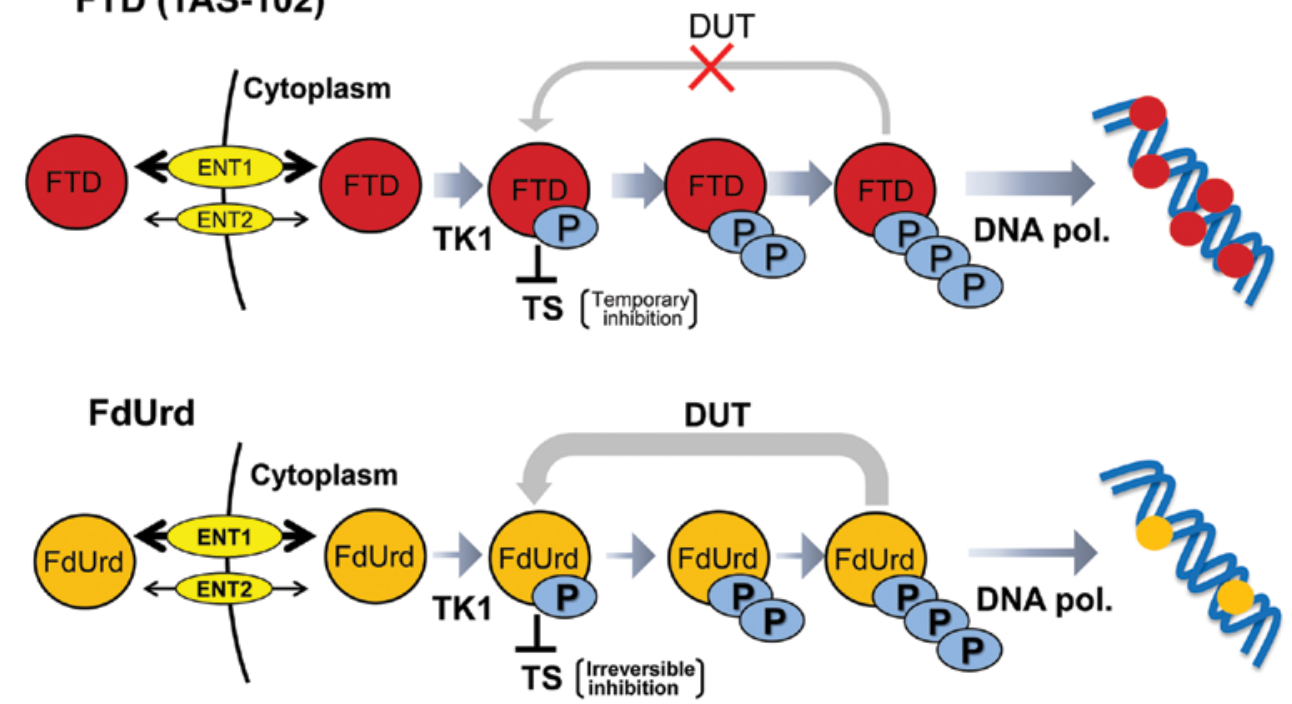

Figure 6. A potential mechanism of FTD and FdUrd incorporation into DNA via the dThd salvage pathway. In this model, both FTD and FdUrd are transported by both ENT1 and ENT2. The catalytic efficiency of TK1 for FTD phosphorylation is higher than that for FdUrd. FdUrd-triphosphate is degraded by DUT, while FTD-triphosphate is not a DUT substrate. Consequently, FTD incorporates into DNA effectively, compared with FdUrd.

irreversibly inhibits TS through the formation of a covalent bond, whereas $\mathrm{F}_{3} \mathrm{dTMP}$ inhibits TS in a reversible manner. Short-term TS inhibition by $\mathrm{F}_{3} \mathrm{dTMP}$ is not sufficient to cause cytotoxicity, but may still deplete dTMP and dTTP, enabling $\mathrm{F}_{3}$ TTP to be incorporated into DNA at a higher level.

FTD is resistant to degradation by DUT, suggesting that TAS-102 could be effective against tumors resistant to 5-FU because of elevated DUT expression (31). In addition, several investigators have shown that patients with high TK1 expression have a relatively poor prognosis with some tumor types (32). These findings indicate that TK1 overexpression represents a cancer-specific pathway and that TAS-102 treatment can improve the poor prognosis of metastatic colorectal cancer patients who are refractory to standard chemotherapies, including 5-FU.

From the viewpoint of FTD resistance, the downregulation of nucleoside transporters and TK1 involved in the dThd salvage pathway results in ineffective therapy against cancer cells (23). These factors indicate that FTD-resistant cells may rely on de novo dThd synthesis as an alternative means of dThd production. A TS inhibitor cocktail involving 5-fluoropyrimidines and/or anti-folates may be a good choice in treating FTD-resistant cancer. Modulating dThd synthesis by 5-FU and FTD could be an effective cancer therapy.

The DNA repair system removes DNA damage sites from the genome, making it one of the determinants of 5-fluoropyrimidine efficacy (33). We could not analyze FdUrd efflux from DNA because of its low level of DNA incorporation. However, the elimination ratio of FTD was similar to that observed with the natural substrate dThd. This phenomenon implies that FTD is stably incorporated into DNA at the same level as dThd. It is reported that uracil DNA glycosylases, thymine DNA glycosylase, and the methyl-CpG binding domain 4 protein recognize 5-FU (but not FTD) and that they may contribute to FTD incorporation into DNA. However, further studies should be performed to confirm the associated FTD antitumor mechanisms at play following DNA incor- poration, including potential involvements of DNA repair systems.

In conclusion, evidence presented here suggests that TAS-102 consisting of FTD and TPI is the first dThd-based antitumor agent whose main mechanism is the inhibition of DNA incorporation itself. Further studies regarding mechanisms occurring after DNA incorporation, as well as combination therapies with other antitumor agents may be needed to improve targeted cancer chemotherapy.

\section{Acknowledgements}

The authors are indebted to Professor Godefridus J. Peters of the Department of Oncology of the VU University Medical Center for providing scientific advice. We also thank Tokai Electron Microscopy (Nagoya, Japan) for providing technical assistance for the electron microscopy experiments. We would like to thank Editage (www.editage.jp) for English language editing.

\section{References}

1. Hu J, Locasale JW, Bielas JH, O'Sullivan J, Sheahan K, Cantley LC, Vander Heiden MG and Vitkup D: Heterogeneity of tumor-induced gene expression changes in the human metabolic network. Nat Biotechnol 31: 522-529, 2013.

2. Weber G: Biochemical strategy of cancer cells and the design of chemotherapy: G. H. A. Clowes Memorial Lecture. Cancer Res 43: 3466-3492, 1983.

3. Heidelberger C, Chaudhuri NK, Danneberg P, Mooren D, Griesbach L, Duschinsky R, Schnitzer RJ, Pleven E and Scheiner J: Fluorinated pyrimidines, a new class of tumourinhibitory compounds. Nature 179: 663-666, 1957.

4. Muggia FM, Peters GJ and Landolph JR Jr: XIII International Charles Heidelberger Symposium and 50 Years of Fluoropyrimidines in Cancer Therapy Held on September 6 to 8, 2007 at New York University Cancer Institute, Smilow Conference Center. Mol Cancer Ther 8: 992-999, 2009.

5. Johnston PG, Benson AB III, Catalano P, Rao MS, O'Dwyer PJ and Allegra CJ: Thymidylate synthase protein expression in primary colorectal cancer: Lack of correlation with outcome and response to fluorouracil in metastatic disease sites. J Clin Oncol 21: 815-819, 2003. 
6. Leichman CG: Predictive and prognostic markers in gastrointestinal cancers. Curr Opin Oncol 13: 291-299, 2001.

7. Shintani M, Urano M, Takakuwa Y, Kuroda M and Kamoshida S: Immunohistochemical characterization of pyrimidine synthetic enzymes, thymidine kinase- 1 and thymidylate synthase, in various types of cancer. Oncol Rep 23: 1345-1350, 2010.

8. Sherley JL and Kelly TJ: Regulation of human thymidine kinase during the cell cycle. J Biol Chem 263: 8350-8358, 1988.

9. Arnér ES and Eriksson S: Mammalian deoxyribonucleoside kinases. Pharmacol Ther 67: 155-186, 1995.

10. Heidelberger C, Parsons DG and Remy DC: Syntheses of 5-trifluoromethyluracil and 5-trifluoromethyl-2'-Deoxyuridine. J Med Chem 7: 1-5, 1964.

11. Ansfield FJ and Ramirez G: Phase I and II studies of 2'-deoxy-5(trifluoromethyl)-uridine (NSC-75520). Cancer Chemother Rep 55: 205-208, 1971.

12. Skevaki CL, Galani IE, Pararas MV, Giannopoulou KP and Tsakris A: Treatment of viral conjunctivitis with antiviral drugs. Drugs 71: 331-347, 2011.

13. Fukushima M, Suzuki N, Emura T, Yano S, Kazuno H, Tada Y, Yamada Y and Asao T: Structure and activity of specific inhibitors of thymidine phosphorylase to potentiate the function of antitumor 2'-deoxyribonucleosides. Biochem Pharmacol 59: 1227-1236, 2000 .

14. Temmink OH, Emura T, de Bruin M, Fukushima $M$ and Peters GJ: Therapeutic potential of the dual-targeted TAS-102 formulation in the treatment of gastrointestinal malignancies Cancer Sci 98: 779-789, 2007.

15. Yoshino T, Mizunuma N, Yamazaki K, Nishina T, Komatsu Y, Baba H, Tsuji A, Yamaguchi K, Muro K, Sugimoto N, et al: TAS-102 monotherapy for pretreated metastatic colorectal cancer: A double-blind, randomised, placebo-controlled phase 2 trial. Lancet Oncol 13: 993-1001, 2012.

16. Emura T, Nakagawa F, Fujioka A, Ohshimo H, Yokogawa T, Okabe $\mathrm{H}$ and Kitazato K: An optimal dosing schedule for a novel combination antimetabolite, TAS-102, based on its intracellular metabolism and its incorporation into DNA. Int J Mol Med 13: 249-255, 2004

17. Tanaka N, Sakamoto K, Okabe H, Fujioka A, Yamamura K, Nakagawa F, Nagase H, Yokogawa T, Oguchi K, Ishida K, et al: Repeated oral dosing of TAS-102 confers high trifluridine incorporation into DNA and sustained antitumor activity in mouse models. Oncol Rep 32: 2319-2326, 2014.

18. Eckstein JW, Foster PG, Finer-Moore J, Wataya $Y$ and Santi DV: Mechanism-based inhibition of thymidylate synthase by 5-(trifluoromethyl)-2'-deoxyuridine 5'-monophosphate. Biochemistry 33: 15086-15094, 1994.

19. Temmink OH, Comijn EM, Fukushima $M$ and Peters GJ Intracellular thymidylate synthase inhibition by trifluorothymidine in FM3A cells. Nucleosides Nucleotides Nucleic Acids 23 . 1491-1494, 2004

20. Reyes $P$ and Heidelberger C: Fluorinated pyrimidines. XXVI. Mammalian thymidylate synthetase: Its mechanism of action and inhibition by fluorinated nucleotides. Mol Pharmacol 1: 14-30, 1965.

21. Belt JA and Noel LD: Isolation and characterization of a mutant of L1210 murine leukemia deficient in nitrobenzylthioinosineinsensitive nucleoside transport. J Biol Chem 263: 13819-13822, 1988.
22. Heidelberger C: Fluorinated pyrimidines. Prog Nucleic Acid Res Mol Biol 4: 1-50, 1965.

23. Temmink OH, Bijnsdorp IV, Prins HJ, Losekoot N, Adema AD, Smid K, Honeywell RJ, Ylstra B, Eijk PP, Fukushima M, et al: Trifluorothymidine resistance is associated with decreased thymidine kinase and equilibrative nucleoside transporter expression or increased secretory phospholipase A2. Mol Cancer Ther 9: 1047-1057, 2010.

24. Ladner RD, Lynch FJ, Groshen S, Xiong YP, Sherrod A, Caradonna SJ, Stoehlmacher J and Lenz HJ: dUTP nucleotidohydrolase isoform expression in normal and neoplastic tissues: Association with survival and response to 5-fluorouracil in colorectal cancer. Cancer Res 60: 3493-3503, 2000.

25. Temmink $\mathrm{OH}$, de Bruin M, Comijn EM, Fukushima $\mathrm{M}$ and Peters GJ: Determinants of trifluorothymidine sensitivity and metabolism in colon and lung cancer cells. Anticancer Drugs 16: 285-292, 2005

26. Kobayashi D, Nozawa T, Imai K, Nezu J, Tsuji A and Tamai I: Involvement of human organic anion transporting polypeptide OATP-B (SLC21A9) in pH-dependent transport across intestinal apical membrane. J Pharmacol Exp Ther 306: 703-708, 2003.

27. Williams MV and Cheng Y: Human deoxyuridine triphosphate nucleotidohydrolase. Purification and characterization of the deoxyuridine triphosphate nucleotidohydrolase from acute lymphocytic leukemia. J Biol Chem 254: 2897-2901, 1979.

28. Ward JL, Sherali A, Mo ZP and Tse CM: Kinetic and pharmacological properties of cloned human equilibrative nucleoside transporters, ENT1 and ENT2, stably expressed in nucleoside transporter-deficient PK15 cells. Ent2 exhibits a low affinity for guanosine and cytidine but a high affinity for inosine. J Biol Chem 275: 8375-8381, 2000.

29. Parsels LA, Parsels JD, Wagner LM, Loney TL, Radany EH and Maybaum J: Mechanism and pharmacological specificity of dUTPase-mediated protection from DNA damage and cytotoxicity in human tumor cells. Cancer Chemother Pharmacol 42: 357-362, 1998.

30. Wilson PM, LaBonte MJ, Lenz HJ, Mack PC and Ladner RD: Inhibition of dUTPase induces synthetic lethality with thymidylate synthase-targeted therapies in non-small cell lung cancer. Mol Cancer Ther 11: 616-628, 2012.

31. Nobili S, Napoli C, Landini I, Morganti M, Cianchi F, Valanzano R, Tonelli F, Cortesini C, Mazzei T and Mini E: Identification of potential pharmacogenomic markers of clinical efficacy of 5-fluorouracil in colorectal cancer. Int J Cancer 128: 1935-1945, 2011

32. Aufderklamm S, Todenhöfer T, Gakis G, Kruck S, Hennenlotter J, Stenzl A and Schwentner C: Thymidine kinase and cancer monitoring. Cancer Lett 316: 6-10, 2012.

33. Meyers M, Wagner MW, Hwang HS, Kinsella TJ and Boothman DA: Role of the hMLH1 DNA mismatch repair protein in fluoropyrimidine-mediated cell death and cell cycle responses. Cancer Res 61: 5193-5201, 2001. 